\title{
Tillering dynamics in spring and summer of marandu palisade grass pastures previously used under deferred grazing
}

\author{
[Dinâmica de perfilhamento na primavera e no verão de pastagens de capim-marandu \\ previamente utilizadas sob pastejo diferido] \\ B.H.R. Carvalho ${ }^{1}$ (D) J.A. Martuscello ${ }^{(1)}$, G.O. Rocha ${ }^{(D)}$, N.A.M. Silva1 ${ }^{(D)}$, \\ G.S. Borges ${ }^{1}$ (D), M.E.R. Santos ${ }^{1 *(D)}$ \\ ${ }^{1}$ Universidade Federal de Uberlândia, Escola de Medicina Veterinária, Uberlândia, MG, Brasil \\ ${ }^{2}$ Universidade Federal de São João Del-Rei, São João Del-Rei, MG, Brasil
}

\begin{abstract}
This work was conducted to evaluate the effect of deferred pasture condition of Brachiaria brizantha cv. Marandu in the late winter on tillering during the growing season. The treatments were three pasture conditions at late winter: short pasture, tall pasture and tall/mown pasture. In September and October, tiller appearance rate $(\mathrm{TApR})$ and tiller mortality rate $(\mathrm{TMoR})$ were greater in the tall/mown pasture. In November and December, tall pasture presented greater TApR. From November to January the TMoR was greater in the tall pasture. The tiller stability index of short and tall/mown pastures were greater in October. The short pasture presented a greater tiller number than the tall and tall/mown pastures during the entire experimental period. Deferred and short pasture of marandu palisade grass at late winter presents in general lower tiller mortality and higher population density of tillers from the early spring onwards, in comparison to tall pasture. The mowing of marandu palisade grass with high forage mass at the late winter, although it only temporarily compromises the population stability of tillers, also stimulates its fast tillering from spring on.
\end{abstract}

Keywords: Brachiaria brizantha syn. Urochloa brizantha, mowed, sward height, stability index, tiller

\section{RESUMO}

Este trabalho foi conduzido com o objetivo de avaliar o efeito da condição da pastagem diferida de Brachiaria brizantha $c v$. Marandu ao final do inverno sobre o perfilhamento durante a estação de crescimento. Os tratamentos foram três condições de pastagem no final do inverno: pasto baixo, pasto alto e pasto alto/roçado. Nos meses de setembro e outubro, a taxa de aparecimento de perfilhos (TApP) $e$ a taxa de mortalidade de perfilhos (TMoP) foram maiores na pastagem alta/roçada. Nos meses de novembro e dezembro, a pastagem alta apresentou maior TApP. De novembro a janeiro, a TMoP foi maior na pastagem alta. Os índices de estabilidade de perfilhos das pastagens baixas e altas/roçadas foram maiores em outubro. A pastagem baixa apresentou maior número de perfilhos do que as pastagens altas e altas/roçadas durante todo o período experimental. A pastagem diferida e baixa de capimmarandu no final do inverno apresenta, em geral, menor mortalidade de perfilhos e maior densidade populacional de perfilhos no início da primavera, em comparação com a pastagem alta. A roçada do capim-marandu com alta massa de forragem ao final do inverno, embora comprometa apenas temporariamente a estabilidade populacional dos perfilhos, também estimula o perfilhamento rápido a partir da primavera.

Palavras-chave: altura do dossel, Brachiaria brizantha Syn. Urochloa brizantha, índice de estabilidade, perfilho, roçada

*Corresponding author: manoel.rozalino@ufu.com

Submitted: February 9, 2021. Accepted: June 15, 2021. 


\section{INTRODUCTION}

Tillers are the growth units of forage grasses and, therefore, variations in appearance and mortality of tiller during the year determine, in part, the perenniality and stability (Caminha et al., 2010; Silva et al., 2017), herbage production (Sbrissia et al., 2018) and morphological characteristics (Santos et al., 2017) of pasture. The natural tillering pattern is influenced by the current climate in each season. In the Southeastern and Central-Western regions of Brazil the appearance and mortality of tillers are greater during the spring, what usually extends to the summer. However, in the autumn, the emergence of tillers begins to reduce, reaching minimum levels in the winter. As compensation, tiller mortality is usually low during fall and winter (Sbrissia et al., 2010; Silva et al., 2015).

The renewal of the tillers in the pasture is also modified by pasture management strategies (Fialho et al., 2012; Montagner et al., 2012; Silva et al., 2015), such as deferment of pasture (Santos et al., 2018), that consists of removing the animals from the pasture (grazing exclusion) at the end of the plant growing season. With this, it is possible to guarantee a forage stock for use, under grazing, in the period of low or no pasture growth. In this sense, it is common for deferred pastures to have taller heights in early winter and by the end of winter the height is decreased because of grazing (Santos et al., 2009; Silva et al., 2016). The magnitude of the height and forage mass values of the deferred pastures at the late winter depends on the pasture management.

In the short and deferred pastures in the late winter the tillering is expected to be faster and more intense in the next seasons (Santana et al., 2014), due to the greater incidence of light on the basal buds, which stimulates their development in new tillers (Sousa et al., 2013). In contrast, in tall and deferred pastures, the greater selfshading inside the canopy can reduce tillering in subsequent spring and summer (Santana et al., 2014).

In addition, the mowing of tall pasture in the winter, despite providing the removal of old forage, results in great amount of forage on the base of the plants, which can inhibit the incidence of light on the basal buds and, consequently, can reduce tillering and compromise the number of tillers in the pastures. However, this hypothesis hasn't yet been tested.

This study was conducted in pastures of Brachiaria brizantha cv. Marandu syn. Urochloa brizantha cv. Marandu in order to (1) verify if the deferred and short pastures at the late winter presents greater and more rapid renovation of tiller during the spring and summer, when compared to deferred and tall pastures; and (2) understand how the mowing of taller pastures at the late winter modifies the tiller's turnover in spring and summer. Based on this information, it is possible to idealize pasture management strategies that optimize the natural pattern of tiller renewal during the beginning of growing season.

\section{MATERIAL AND METHODS}

This study was carried from January 2014 to February 2015, at the Experimental Capim Branco Farm, belonging to the Federal University of Uberlândia, in Uberlândia, MG, Brazil (18 53'19" S, 48 $20^{\circ} 57^{\prime \prime} \mathrm{W}$ and $835 \mathrm{~m}$ a.s.1). The experimental area was a pasture of Brachiaria brizantha syn. Urochloa brizantha cv. Marandu (marandu palisade grass) subdivided into nine paddocks (experimental units) of $800 \mathrm{~m}^{2}$ each. In January 2014, soil samples were taken for analysis of the fertility level, whose results were: $\mathrm{pH}$ in $\mathrm{H}_{2} \mathrm{O}$ : 6.0 ; $\mathrm{P}: 6.3$ (mehlich-1) and $\mathrm{K}: 153.0 \mathrm{mg} \mathrm{dm}^{-3} ; \mathrm{Ca}^{+2}: 5.0$ $\mathrm{cmol}_{\mathrm{c}} \mathrm{dm}^{-3} ; \mathrm{Mg}^{+2}$ : $2.0 \mathrm{cmol}_{\mathrm{c}} \mathrm{dm}^{-3}$ and $\mathrm{Al}^{3+}: 0.0$ $\mathrm{cmol}_{\mathrm{c}} \mathrm{dm}^{-3}(1 \mathrm{~mol} \mathrm{KCl} \mathrm{L}-1)$; base sum: $7.4 \mathrm{cmol}_{\mathrm{c}}$ $\mathrm{dm}^{-3}$; effective CEC: $7.4 \mathrm{cmol}_{\mathrm{c}} \mathrm{dm}^{-3}$; total CEC: $11.0 \mathrm{cmol}_{\mathrm{c}} \mathrm{dm}^{-3}$; base saturation: $69.0 \%$. Based on these results, $50 \mathrm{~kg} \mathrm{ha}^{-1}$ of $\mathrm{P}_{2} \mathrm{O}_{5}$ and $\mathrm{N}$ were applied in January 2014.

According to Köppen's classification, the climate of the region is the Aw-type, tropical savannah, with mild and dry winter, and dry and rainy seasons well defined (Alvares et al., 2013). Climatic conditions were monitored at a meteorological station located about $200 \mathrm{~m}$ from the experimental area (Fig. 1). 


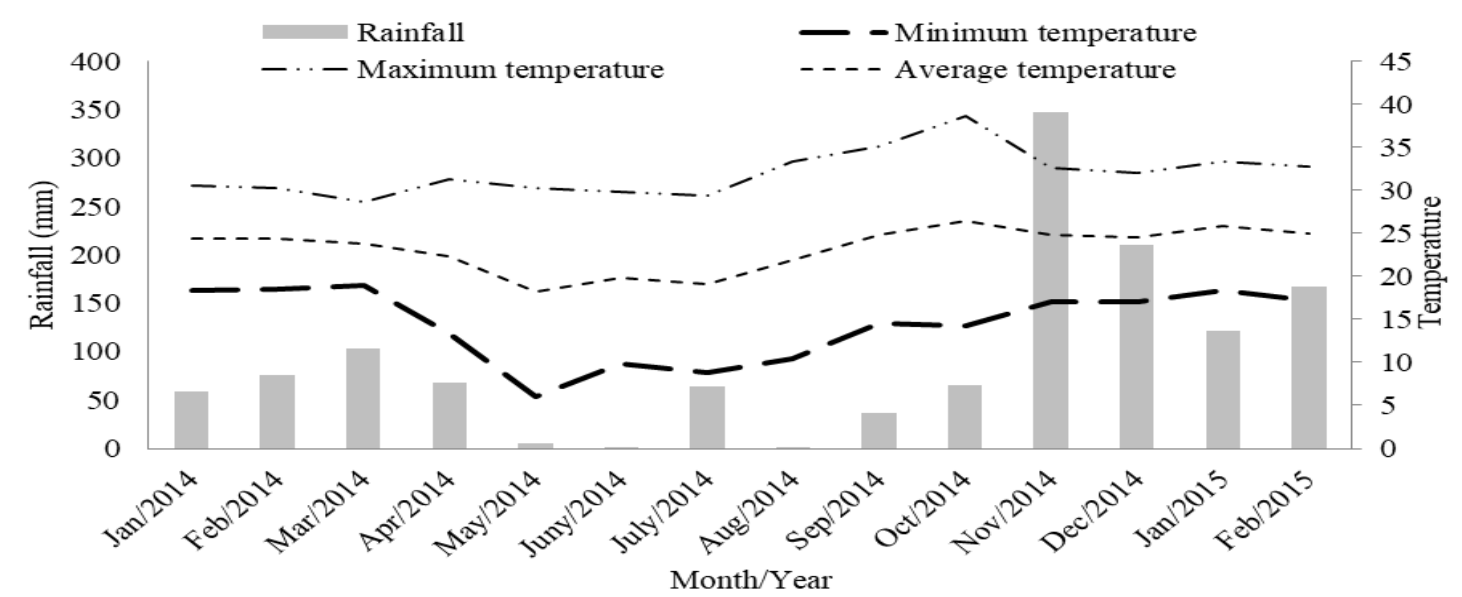

Figure 1. Accumulated rainfall, and minimum, average and maximum daily temperatures $\left({ }^{\circ} \mathrm{C}\right)$ from January 2014 to March 2015.

From January 2014 to March 17, 2014, all pastures were managed with continuous stocking using sheep at a variable stocking rate to maintain pastures with three medium heights (15, 35 and $45 \mathrm{~cm})$. The heights were measured weekly with a ruler in 30 points per paddock, considering the distance from the soil surface to the highest live leaves in the pasture. The pasture height control occurred with addition or withdrawal of lambs ( $30 \mathrm{~kg}$ of body weight) from the paddocks.

On March 17, 2014 all pastures were deferred for 92 days. Posteriorly, the grazing period started, in which the paddocks were managed in continuous stocking with sheep and the stocking rate corresponded, on average to 4.0 animal unit/ha (one animal unit corresponded to $450 \mathrm{~kg}$ of body weight). At the end of the grazing period (82 days), on September 7, 2014 pastures deferred at $15 \mathrm{~cm}$ were short $(24.1 \mathrm{~cm}$ and $2.420 \mathrm{~kg} \mathrm{ha}^{-1} \mathrm{of} \mathrm{DM}$ ) and pastures deferred at 35 $\mathrm{cm}$ reached $49 \mathrm{~cm}$ and forage mass with $3.837 \mathrm{~kg}$ $\mathrm{ha}^{-1}$ of DM, which was similar to those deferred at $45 \mathrm{~cm}\left(50 \mathrm{~cm}\right.$ and $\left.4.211 \mathrm{~kg} \mathrm{ha}^{-1} \mathrm{DM}\right)$. In order to cause differences in the conditions of pastures deferred at 35 and $45 \mathrm{~cm}$, the remaining forage of pastures deferred at $45 \mathrm{~cm}$ was cut to $8 \mathrm{~cm}$ on September 17, 2014. Thus, it was possible to obtain three pasture conditions at the end of winter (short, tall and tall/mown), which corresponded to our experimental treatments and were evaluated during September 2014 to February 2015 (grazing period in the spring and summer). The three treatments were distributed in a completely randomized design, with three replications and totaling nine experimental units (paddocks).

From September 17, 2014 on, all pastures remained without animals for 75 days, until the new tillers from spring regrowth reached $30 \mathrm{~cm}$ of height on average, when the grazing period was started. During this grazing period, all pastures were managed at $30 \mathrm{~cm}$ of average height (Silva et al., 2013), with continuous stocking and variable stocking rate, using sheep (30kg of body weight), which had unrestricted access to the mineral salt and water. The pasture height control was performed weekly and, on average, its value was $34 \mathrm{~cm}$.

The tillering dynamics were evaluated in three representative areas of $0.07 \mathrm{~m}^{2}$ per experimental unit. These areas were demarcated using a PVC ring of $30 \mathrm{~cm}$ in diameter, which were fixed to the ground with wire clips. All the tillers within the ring were counted and marked on September 04, 2014, and the new tillers were counted and remarked every 30 days with new clips coated with plastic of different color to identify each generation until on February 02, 2015. Data generated were used to calculate the rates of tiller appearance and mortality, the stability index and the number of tillers in the pastures (Sbrissia et al., 2010). Curves of monthly variation of the number of generations of tillers were also generated. 
Statistical analysis was performed using the analysis of variance in a completely randomized design with three repetitions, using the PROC MIXED of SAS ${ }^{\circledR}$. The covariance matrices were chosen using the Akaike criterion (Wolfinger, 1993). The pasture condition was considered as fixed effect. The months of the grazing period were considered measures repeated over time. To analyze data the means averages were compared by the Student Newman Keuls test $(\mathrm{P}<0.05)$.

\section{RESULTS AND DISCUSSION}

All the characteristics of tillering dynamics were influenced by the interaction between pasture conditions at the late winter and the months of the year (Table 1).

In September and October, tiller appearance rate (TApR) was greater in the tall/mown pasture than in the short and tall pastures. However, in November and December, the tall pastures presented greater TApR, when compared to the others. In January, short and tall/mown pasture presented greater TApR than the tall pasture. In the short pasture, lower TApR occurred in September, rapidly it reached its greatest value in October. In the other months of the year, TApR was intermediate and similar.

Table 1. Characteristics of the dynamics of tillering in spring and summer according to the condition of the marandu palisade grass pastures in late winter and after its use under grazing delayed

\begin{tabular}{|c|c|c|c|c|}
\hline \multirow{2}{*}{ Month } & \multicolumn{3}{|c|}{ Pasture condition at late winter } & \multirow[t]{2}{*}{ SEM } \\
\hline & Short & Tall & Tall/mown & \\
\hline \multicolumn{5}{|c|}{ Tiller appearance rate (\% in 30 days) } \\
\hline September & $7.6 \mathrm{Cc}$ & $15.2 \mathrm{ABb}$ & $39.2 \mathrm{Ba}$ & 9.5 \\
\hline October & $39.6 \mathrm{Ab}$ & $20.2 \mathrm{Ac}$ & $94.8 \mathrm{Aa}$ & 22.3 \\
\hline November & $14.9 \mathrm{Bb}$ & $22.2 \mathrm{Aa}$ & $14.4 \mathrm{Cb}$ & 2.5 \\
\hline December & $20.5 \mathrm{Bab}$ & $24.4 \mathrm{Aa}$ & $13.2 \mathrm{Cb}$ & 3.3 \\
\hline January & $19.7 \mathrm{Ba}$ & $10.5 \mathrm{Bb}$ & $22.0 \mathrm{Ca}$ & 3.5 \\
\hline \multicolumn{5}{|c|}{ Tiller mortality rate (\% in 30 days) } \\
\hline September & 7.9Bb & $2.2 \mathrm{Cc}$ & 80.8Aa & 25.3 \\
\hline October & $6.6 \mathrm{Bb}$ & $8.3 \mathrm{Bb}$ & $17.7 \mathrm{Ba}$ & 3.5 \\
\hline November & $12.2 \mathrm{ABb}$ & $20.6 \mathrm{Aa}$ & $14.3 \mathrm{Bb}$ & 2.5 \\
\hline December & $16.2 \mathrm{Ab}$ & 19.4Aa & $6.7 \mathrm{Cc}$ & 3.8 \\
\hline January & 13.0ABab & $16.5 \mathrm{ABa}$ & $9.9 \mathrm{Cc}$ & 1.9 \\
\hline \multicolumn{5}{|c|}{ Stability index } \\
\hline September & $0.99 \mathrm{aB}$ & $1.13 \mathrm{aAB}$ & $0.27 b C$ & 0.3 \\
\hline October & $1.30 \mathrm{bA}$ & $1.10 \mathrm{cAB}$ & $1.60 \mathrm{aA}$ & 0.1 \\
\hline November & $1.01 \mathrm{aB}$ & $0.97 \mathrm{aA}$ & $0.98 \mathrm{aB}$ & 0.0 \\
\hline December & $1.01 \mathrm{aB}$ & $1.00 \mathrm{aA}$ & $1.06 \mathrm{aB}$ & 0.0 \\
\hline January & $1.04 \mathrm{abB}$ & $0.92 \mathrm{bB}$ & $1.10 \mathrm{aB}$ & 0.1 \\
\hline \multicolumn{5}{|c|}{ Tiller $\mathrm{m}^{-2}$} \\
\hline September & $717 \mathrm{aB}$ & $434 \mathrm{bB}$ & $621 \mathrm{abA}$ & 83 \\
\hline October & $715 \mathrm{aB}$ & 491abB & $363 \mathrm{bB}$ & 103 \\
\hline November & $951 \mathrm{aA}$ & $552 \mathrm{bAB}$ & $643 \mathrm{bA}$ & 121 \\
\hline December & $977 \mathrm{aA}$ & $580 \mathrm{bAB}$ & $644 \mathrm{bA}$ & 123 \\
\hline January & $1019 \mathrm{aA}$ & $628 \mathrm{bA}$ & $686 \mathrm{bA}$ & 122 \\
\hline
\end{tabular}

SEM: standard error of the mean; For each characteristic, averages followed by the same letter, upper case in the column and lowercase in the row, did not differ by the Student Newman Keuls test $(\mathrm{P}>0.05)$.

In all pastures, September was a month with low TApR (Table 1), due to the adverse weather conditions in this period, which was characterized by low rainfall (Fig. 1). However, in October, the TApR increased in all pastures, due to improvements in the climatic conditions. This increase was more accentuated in the tall/mown pasture, intermediate in the short pasture and lower in the tall pasture (Table 1). Short pasture, because of the lower grass height $(24.1 \mathrm{~cm})$ and forage mass $\left(2.420 \mathrm{~kg} \mathrm{ha}^{-1}\right.$ of DM) in the month of September had probably intercepted less light in the beginning of spring. Thus, it is likely that more light has been applied to the base of the plants, which may have stimulated the appearance of basal tillers (Sousa 
et al., 2013). In this sense, Santana et al. (2014) also found an increase of tiller appearance rate on $B$. decumbens swards in early spring, due to the decrease in sward height at the beginning of the previous deferment period.

In September and October, the tiller mortality rate (TMoR) was greater in the tall/mown pasture than in the low and tall pastures. However, during the other months the TMoR was greater in the tall pasture in comparison to the others. In general, short and tall pastures had lower TMoR in September and October, but for tall/mown the TMoR was lower in December and January, compared to other months.

In September and October, the tall/mown pasture presented greater tiller appearance rate (TApR) and tiller mortality rate (TMoR), compared to short and tall pastures (Table 1).

This high tillering occurred even with the deposition of large amounts of forage, coming from the mowing, on the base of the plants. It was hypothesized that this forage could inhibit tillering, because of the shading of the basal buds. However, this expectation was not confirmed in this study. When the mowing occurred, many tillers had their apical meristem eliminated and, consequently, they died. At the same time, the loss of the apical meristem of the tiller may have prevented the apical dominance process from occurring. Consequently, many basal buds have developed into new tillers (Matthew et al., 2000). The high stock of organic reserves of tall/mown pastures in the early spring may also have contributed to its intense tillering in this period. In this context, is possible that deferred pastures have accumulated a high amount of reserve compounds during the deferment period, in the autumn. This reserve may have been little used in the winter due to the low pasture growth (Silva et al., 2014). Thus, the stock of reserve compounds may have been enough to allow high tillering of tall/mown pasture in early spring. It is important to emphasize that this hypothesis still needs to be tested.

The tiller population stability can be evaluated by the stability index (SI). When its value is equal to 1 , the tiller population remains stable. Values below 1 mean that the appearance of new tillers would not be large enough, in relation to their mortality, to maintain population density.
On the other hand, values higher than 1 indicate a tendency of increase in the population of tiller (Bahmani et al., 2003; Caminha et al., 2010). In this context, the short and tall/mown pastures were greater in October than in the other months. Conversely, it had the lowest values in September. For the tall pasture, the SI was similar for all months of the year. In the following months, SI did not vary among pastures conditions (Table 1).

Based on the SI values obtained in this work (Table 1), it can be stated that the stability of the tiller population was only compromised in September in the tall/mown pasture, due to the high TMoP, which wasn't compensated by TApP (Table 1). However, after this short period (September), the tall/mown pasture, as well as the others, showed stability of the tiller population (Table 1).

In general, the short pasture presented a greater tiller number than the tall and tall/mown pastures during the whole experimental period. Tiller population density of short and tall pastures was higher in November, December and January compared to September and October. On the tall/mown pasture the lowest tiller number occurred in the October (Table 1).

The intense tillering in October and the stability of the tiller population in the pastures (Table 1) resulted in an increase in the population density of tillers in all pastures from October to January (Table 1). The greater number of tillers in the pastures from November on may have caused greater LAI and, consequently, greater shading at the plants base. This factor may have been responsible for the constancy of TApR from November to January in the short and tall/mown pastures (Table 1).

In the tall/mown pastures first there was a high TMoR in September and later, in October, high TApR was observed. Therewith, the stability index (SI) of tillers population was very low in September (Fig. 2C), which resulted in a marked decrease in population density of tillers from September to October (Table 1). However, the high TApR in October caused the SI to rise this month (Fig. 2C) and the population density of tillers increased from October to November (Table 1). These factors indicate the full recovery 
of the tiller population, which had been greatly

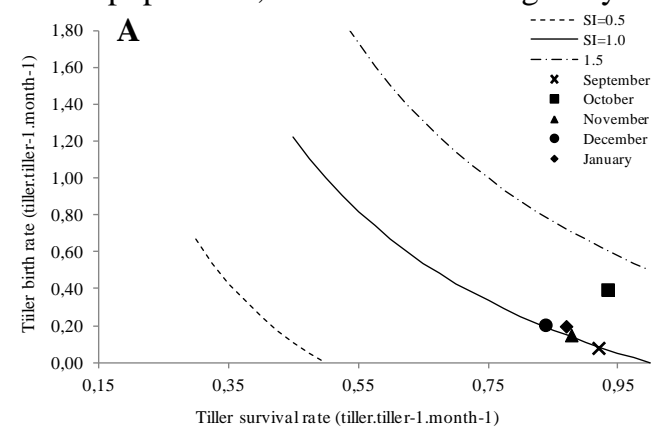

reduced with the mowing of the tall grasses.
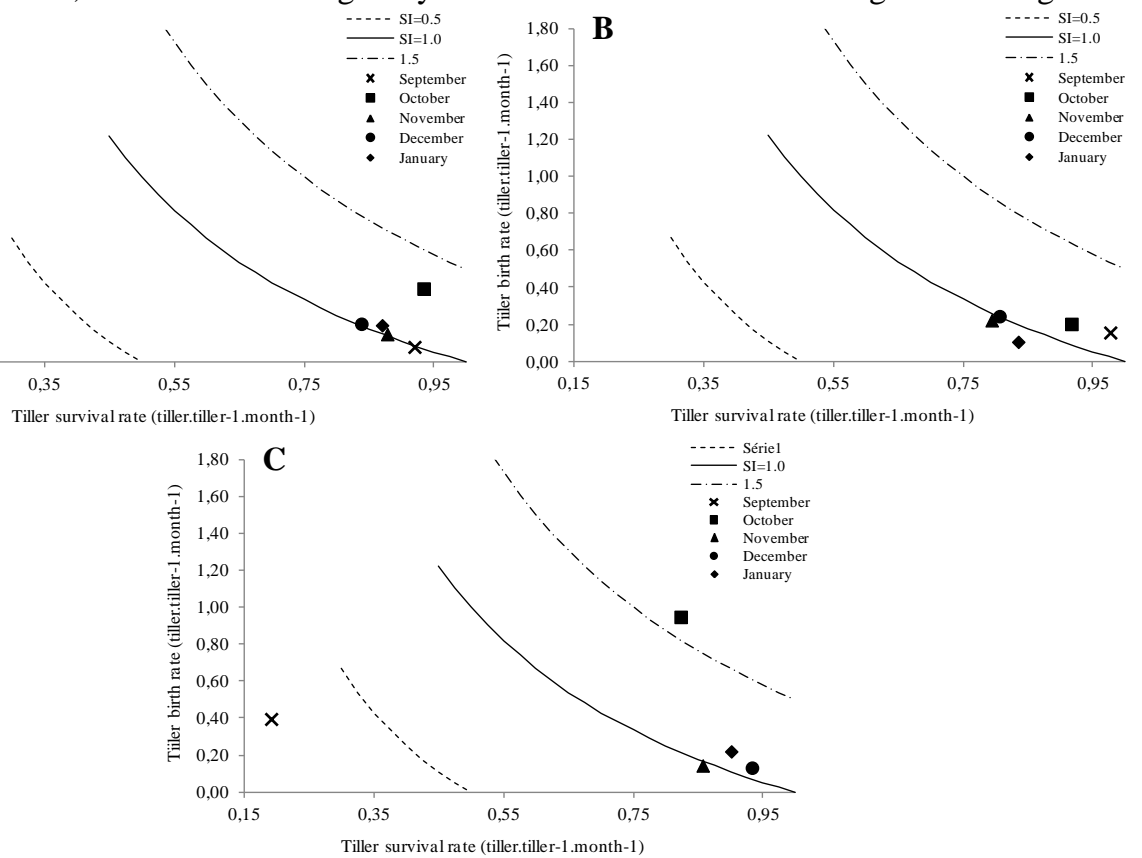

Figure 2. Seasonal diagram of tiller population stability index (SI) on continuously stocked marandu palisade grass with three pasture conditions at the late winter: short (A), tall (B) and tall/mown (C).

It is important to point out that tiller number values at the evaluation site of the tillering dynamics may have been overestimated by the monthly manipulation of the tiller (Sbrissia et al., 2010; Santos et al., 2011). In this context, the possible negative effect of the vegetal residue rooted and deposited on the base of the plants on the tillering could have been minimized by the monthly manipulation of the tillers within the rings of evaluation of the tillering, which could stimulate the tillering.

Based on the analysis of TApR and TMoR data (Table 1), it was observed that the tall/mown pasture presented an earlier renewal of the population of tillers in comparison to the short and tall pastures. In this way, it can be affirmed that the tall/mown pastures showed a younger profile of age group of tillers in early spring, which has important agronomic and zootechnical implications. When compared to the old tillers, young tillers present greater leaf growth rate (Paiva et al., 2011), as well as better structural characteristics (Santos et al., 2018) and nutritive value (Santos et al., 2006). All these characteristics of the young tillers are favorable to the animal grazing.
On the other hand, in the tall pasture, the renewal of the population of tillers was delayed during the spring and the summer. In fact, the increase in TApR was slower in early spring (September and October) in the tall pasture, compared to tall/mown pasture (Table 1 ). In addition, in the tall pasture, the older tillers only died at higher rates from November onwards, when the TMoR was greater in the tall pasture, in relation to the short and tall/mown pastures (Table 1). These results indicate that the tall pasture at the late winter was probably constituted by high percentages of tillers with greater average age, that present lower rate of growth (Montagner et al., 2011; Barbosa et al., 2012); and morphology (Santos et al., 2018) and nutritional value (Santos et al., 2006) limiting the consumption and the animal performance.

In agreement with the previously discussed results and inferences, based on the analysis of the variation of the numbers of the generations of tillers during the experimental period (Fig. 3), it was verified that the older generation of tillers, marked in September, presented 23\%, 22\% and $2 \%$ of participation in the short, tall and tall/mown pastures, respectively, at the end of the experiment, in February of 2015. At the same 
time, the percentage of young tillers, which appeared in the month of January, was 19\%, $11 \%$ and $20 \%$ in short, tall and tall/mown pastures conditions, respectively. These data demonstrate that, at the end of the experiment, the tall/mown pastures were composed of a few old tillers, while the tall pastures contained a few young tillers.

Regarding the monthly variation of tiller generations (Fig. 3), the total number of tillers did not increase in the short pastures from September to October, because the number of tillers of the generation that emerged in September was similar to the number of tillers that died in the same period (Table 1). However, from October to November, there was a marked increase in the total number of tillers in the short pasture (Table 1 and Fig. 3), due to the intense appearance of new tillers in October (Table 1). These increase in the number of tillers in this pasture condition continued in the following months, but at lower intensity (Fig. 3). In the tall pasture, the initial generation of tillers was the lowest when compared to the other pasture conditions (Fig. 3). This is because there was no intense increase in the number of tillers from September to November, as observed for the short pasture. The number of tillers from October to January was low in the tall pasture, which is why the increase in total tiller's density was more discrete in this condition when compared to the others (Fig. 3).
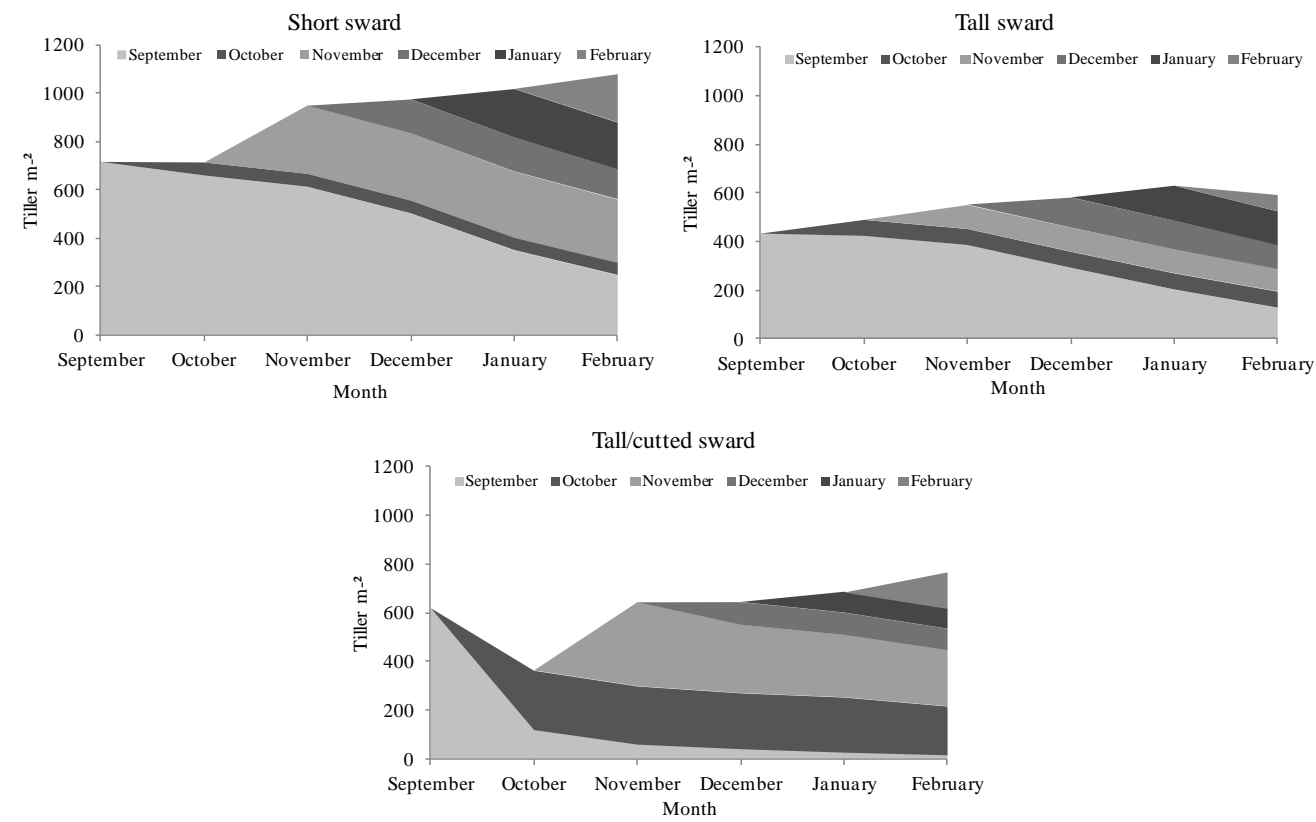

Figure 3 Variation of the number of tiller generations during the experimental period, according to the condition of the marandu palisade grass at the late the winter and after its use under deferred grazing.

The tall/mown pasture showed a drastic decrease in the number of tillers from September to October (Fig. 3), since the mortality of the basal tillers, identified on the first day of evaluation, greatly exceeded the emergence of tillers during this period (Table 1). Afterwards, the tillering generation at the beginning of November was very high, which is why there was an intense increase in the total number of tillers from October to November in the tall/mown pastures. In the following months, there was a gradual increase in the number of tillers, but not in an accentuated way (Fig. 3).

From November on, the tall/mown pasture maintained a tiller population density similar to tall pasture, and both pastures presented a number of tillers lower than the short pasture (Table 1). Short pasture was characterized by high population density of tillers throughout the experimental period, since the beginning of the evaluations, a pattern of response that was constant (Table 1 and Fig. 3). Considering that all pasture was managed with the same average 
height $(30 \mathrm{~cm})$, these results allow inferring that the short pasture probably presented greater volumetric density of the forage. This fact could increase the pasture consumption by grazing animals, considering that, with the same volume of bite, the animal could obtain greater bit mass (Mezzalira et al., 2014). The bit mass is the most determinant factor of the performance of animals kept in pastures (Hodgson, 1990; Fonseca et al., 2013).

The short pasture showed a higher number of tillers at late winter, in September, compared to the high and tall/mown pasture (Table 1 and Fig. 3 ). This may contribute to the higher growth rate of short pasture during the spring, because it is possible that the largest number of tillers will quickly start the appearance and leaf elongation at early growing season, making this pasture less dependent on the appearance of new tillers for start regrowth. This assertion is based on the fact that the leaf appearance in already existing tillers is a less costly process for the plant, in comparison to tiller appearance. However, this hypothesis has yet to be proven. Furthermore, tiller renewal in early spring is still an important mechanism for pasture recovery after winter.

The lower number of tillers in the tall/mown pasture than in the short pasture occurred throughout the experimental period (Table 1 and Fig. 3) and may be related to high tiller mortality at the time of mowing. This reduced the population of base tillers (marked first generation) by $85 \%$, which probably appeared during the previous late summer and autumn. As a result, the high tillering that occurred in spring (from October to November, mainly, Fig. 3) wasn't enough to raise the population density of tillers in tall/mown pasture to level of short pasture.

Based on our results and responding to the objectives proposed in this work, it is possible to state that (1) deferred and short pastures at the late winter presents greater and more rapid renovation of tiller during the spring and summer, when compared to deferred and tall pastures; and (2) the mowing of deferred and taller pastures at late winter compromises only temporarily the population stability of tillers, but latter stimulates the tillering from spring on at level higher than the tall and no mowing pasture at late winter.

\section{CONCLUSIONS}

Short and deferred pasture of Brachiaria brizantha cv. Marandu (marandu palisade grass) in late winter has lower tiller mortality and higher tiller appearance from the early spring onwards, compared to tall pasture. Mowing of marandu palisade grass with high forage mass in late winter also stimulates the tiller appearance rate from spring onwards.

\section{ACKNOWLEDGMENTS}

This work was funded by the Minas Gerais Research Foundation (FAPEMIG) and National Council for Scientific and Technological Development (CNPq). The authors thank the members of TESTHFOR/UFU (Group of Hypothesis Testing in Forage/Federal University of Uberlândia) for their contributions during the field trial setup.

\section{REFERENCES}

ALVARES, C.A.; STAPE, J.L.; SENTELHAS, P.C. et al. Köppen's climate classification map for Brazil. Meteorol. Zeitschrift., v.22, p.711-728, 2013.

BAHMANI, I.; THOM, E.R.; MATTHEW, C. et al. Tiller dynamics od perennial ryegrass cultivars derived from different New Zealand ecotypes: effects of cultivar, season, nitrogen fertilizer, and irrigation. Aust. J. Agric. Res., v.54, p.803-817, 2003.

BARBOSA R.A.; NASCIMENTO JÚNIOR D.; VILELA H.H. et al. Morphogenetic and structural characteristics of guinea grass tillers at different ages under intermittent stocking. Rev. Bras. Zootec., v.41, p.1583-1588, 2012.

CAMINHA, F.O.; SILVA, S.C.; PAIVA, A.J. et al. Estabilidade da população de perfilhos de capimmarandu sob lotação contínua e adubação nitrogenada. Pesqui. Agropecu. Bras., v.45, p.213-220, 2010.

FIALHO, C.A.; SILVA, S.C.; GIMENES, F.M.A. $e t$ al. Tiller population density and tillering dynamics in marandu palisade grass subjected to strategies of rotational stocking management and nitrogen fertilization. Acta Sci. Anim. Sci., v.34, p.245-251, 2012.

FONSECA, L.; CARVALHO, P.C.F.; MEZZALIRA, J.C. et al. Effect of sward surface height and level of herbage depletion on bite features of cattle grazing Sorghum bicolor swards. J. Anim. Sci., v.91, p.4357$4365,2013$. 
HODGSON, J. (Ed.). Grazing management: science into practice. London, UK: Longman Scientific and Technical, 1990. 203p.

MATTHEW, C.; ASSUERO, S.G.; BLACK, C.K.; SACKVILLE-HAMILTON, N.R. Tiller dynamics in grazed swards. In: LEMAIRE, G.; HODGSON, J.; MORAES, A. et al. (Eds.). Grassland ecophysiology and grazing ecology. Cambridge: $\mathrm{CAB}, 2000$. p.127150 .

MEZZALIRA, J.C.; CARVALHO, P.C.F.; LIDIANE, F. et al. Behavioral mechanisms of intake rate by heifers gazing swards of contrating structures. Appl. Anim. Behav. Sci., v.153, p.1-9, 2014.

MONTAGNER, D.B.; NASCIMENTO JÚNIOR, D.; SOUSA, B.M.L.S. et al. Morphogenetic and structural characteristics of tillers of guinea grass of different age and grazing severities. Rev. Bras. Zootec., v.40, p.2105-2110, 2011.

MONTAGNER, D.B.; VILELA, H.H.; CARLOTO, M.N. et al. Tillering dynamics in pastures of guinea grass subjected to grazing severities under intermitent stocking. Rev. Bras. Zootec., v.41, p.544-549, 2012.

PAIVA, A.J.; SILVA, S.C.; PEREIRA, L.E.T. et al. Morphogenesis on age categories of tillers in marandu palisadegrass. Sci. Agr., v.68, p.626-631, 2011.

SANTANA, S.S.; FONSECA, D.M.; SANTOS, M.E.R. et al. Initial height of pasture deferred and utilized in winter and tillering dynamics of signal grass during the following spring. Acta Sci. Anim. Sci., v.36, p.17-23, 2014.

SANTOS, M.E.R.; ÁVILA, A.B.; CARVALHO, A.N. et al. Marandu palisade grass management strategies at the beginning of the deferment period and effects on tillering. Semin. Ciênc. Agr., v.39, p.1617-1626, 2018.

SANTOS, M.E.R.; FONSECA, D.M.; EUCLIDES, V.P.B. et al. Produção de bovinos em pastagens de capim-braquiária diferidas. Rev. Bras. Zootec., v.38, p.635-342, 2009.

SANTOS, M.E.R.; FONSECA, D.M.; GOMES, V.M. et al. Capim-braquiária sob lotação contínua e com altura única ou variável durante as estações do ano: Dinâmica do perfilhamento. Rev. Bras. Zootec., v.40, p.2332-2339, 2011.

SANTOS, M.E.R.; SOUSA, B.M.L.; ROCHA, G.O. et al. Estrutura do dossel e características de perfilhos em pastos de capim-piatã manejados com doses de nitrogênio e períodos de diferimento variáveis. Ciênc. Anim. Bras., v.18, p.1-13, 2017.
SANTOS, P.M.; CORSI, M.; PEDREIRA, C.G.S.; LIMA, C.G. Tiller cohort development and digestibility in Tanzania guinea grass (Panicum maximum cv. Tanzania) under three levels of grazing intensity. Trop. Grassl., v.40, p.84-93, 2006.

SBRISSIA, A.F.; DUCHINI, P.G.; ZANINI, G.D. et al. Defoliation strategies in pastures submitted to intermittent stocking method: underlying mechanisms buffering forage accumulation over a range of grazing heights. Crop Sci., v.58, p.945-954, 2018.

SBRISSIA, A.F.; SILVA, S.C.; SARMENTO, D.O.L. et al. Tillering dynamics in palisadegrass swards continuously stocked by cattle. Plant Ecol., v.206, p.349-359, 2010.

SILVA, C.S.; MONTAGNER, D.B.; EUCLIDES, V.P.B. et al. Steer performance on deferred pastures of Brachiaria brizantha and Brachiaria decumbent. Ciênc. Rural, v.46, p.998-2004, 2016.

SILVA, S.C.; CHIAVEGATO, M.B.; PENA, K.S.; SILVEIRA M.C.T. et al. Tillering dynamics of mulato grass subjected to strategies of rotational grazing management. J. Agric. Sci., v.155, p.1082-1092, 2017.

SILVA, S.C.; GIMENES, F.M.A.; SARMENTO, D.O.L. et al. Grazing behaviour, herbage intake and animal performance of beef cattle heifers on marandu palisade grass subjected to intesities of continuous stocking management. J. Agric. Sci., v.151, p.727-739, 2013.

SILVA, S.C.; PEREIRA, L.E.T.; SBRISSIA, A.F.; HERNANDEZ-GARAY, A. Carbon and nitrogen reserves in marandu palisade grass subjected to intensities of continuous stocking management. $J$. Agric. Sci., v.1, p.1-15, 2014.

SILVA, S.C.; SBRISSIA, A.; PEREIRA, L. Ecophysiology of $\mathrm{C} 4$ forage grasses - undertanding plant growth for optimising their use and management. Agriculture, v.5, p.598-625, 2015.

SOUSA, B.M.L.; SANTOS M.E.R.; VILELA H. H. et al. Piata palisade grass deferred with two distinct initial heights: luminous environment and tillering dynamics. Rev. Bras. Zootec., v.42, p.36-43, 2013.

WOLFINGER, R.D. Covariance structure selection in general mixed models. Commun. Stat. Simul. Comput., v.22, p.1079-1106, 1993. 